\title{
California and Unitary Taxation: The Continuing Saga
}

\section{INTRODUCTION}

In 1986, California allowed multinational corporations (MNC's) a water's edge election as an alternative to worldwide unitary taxation in computing the business's taxable income. ${ }^{1}$ By providing a water's edge election to an MNC, California permitted an MNC to exclude subsidiaries operating outside of the United States from its state income tax return. ${ }^{2}$ Prior to this enactment, an MNC was required to include all foreign subsidiaries on its tax return if they were part of the MNC's unitary business. ${ }^{3}$

The unitary business principle ignores both the separate legal existence of business entities and the geographical boundaries which separate them, and instead, focuses on practical business realities. ${ }^{4}$ In other words, the state treats the group of "related" corporations as a unitary business or one taxpayer. ${ }^{5}$ What is meant by "related" has been the subject of much dispute. ${ }^{6}$ Once the scope of the unitary business is determined, its taxable income is apportioned between the states using a three-factor formula.'

California's adoption of a water's edge election was the result of lobbying efforts by the federal government, United States businesses, and foreign trading partners. ${ }^{8}$

1. Cal. Rev. \& Tax. Code $\ 25110$ (West Supp. 1991). The statute was to be effective January 1, 1988.

2. This statement is subject to considerable modification.

3. Cal. Rev. \& Tax. Code of 25101, 25120-25139 (West 1986).

4. William A. Raabe et al., 1991 Multistate Corporate Tax Guide I-412 (1991).

5. Id.

6. See Allied Signal, Inc. v. Director, Division of Taxation, 112 S.Ct. 2251 (1992); Container Corp: of Am. v. Franchise Tax Bd., 463 U.S. 159 (1983); ASARCO Inc. v. Idaho State Tax Comm'n, 458 U.S. 307 (1982); F.W. Woolworth Co. v. Taxation \& Revenue Dept. 458 U.S. 354 (1982); Exxon Corp. v. Dept. of Revenue of Wisconsin, 447 U.S. 207 (1980); Mobil Oil Corp. v. Commisioner of Taxes of Vermont, 445 U.S. 425 (1980).

7. The formula is equal to:

$$
\frac{\text { Property in state }}{\text { Property everywhere }}+\frac{\text { Payroll in state }}{\text { Payroll everywhere }}+\frac{\text { Sales in state }}{\text { Sales everywhere }}
$$

Divide the result by three for an average of in-state activity.

8. James John Jurinski, California's Water's - Edge Legislation: The Closing Chapter in the Unitary Tax Debate?, 6 J. State Tax'n 23, 25-27 (1987). The United Kindom, Japan and Canada have expressly opposed the use of worldwide unitary taxation. 
Under the threat of federal preemption, and upon the recommendations of the "Working Group" of the Treasury Department, many states abandoned worldwide unitary taxation altogether. Others, like California, retained worldwide unitary taxation, albeit in a modified form.

Some commentators hailed California and four other states' enactments of a water's edge election as the death of unitary taxation of multinational corporations. ${ }^{9}$ Yet California's partial abandonment of worldwide unitary taxation in favor of a water's edge election was an imperfect solution - a solution which will not end the heated debate on unitary taxation. ${ }^{10}$ This note will discuss worldwide unitary taxation, with its strengths and weaknesses, offer conclusions on whether the problems with unitary business were effectively dealt with by California's enactment, and propose a course of action.

\section{BAGKGROUND}

\section{A. Unitary Business and the Division of Net Income Among the States: Butler Bros.}

The term "unitary business" has never been defined by the Supreme Court." The unitary business principle revolves around how closely connected two entities must be in order to be considered a single taxpayer for taxation purposes. ${ }^{12}$ If the two entities do not comprise a unitary business, then the businesses must be treated separately. ${ }^{13}$

In 1942, the Supreme Court decided Butler Bros. v. McColgan, the first case which directly addressed whether the separate entities of a business were sufficiently related to designate them a unitary business. ${ }^{14}$ In Butler Bros., the taxpayer was a Chicago-based wholesaler of dry goods and miscellaneous merchandise. The taxpayer owned seven branches which distributed their goods nationwide. Because one of the branches was located in California, California apportioned by formula the net income of the seven branch offices and the Chicago home office

9. Stephen M. Polit and Stephanie K. Karl, Recent Developments in State and Local Taxation, 19 URB. LAw. 1067, 1088 (1987).

10. During the writing of this paper, Senators Symms and Glenn introduced the Domestic Corporation Taxation Equality Act of 1991 in order to "solve the problems caused by the use of worldwide unitary taxation." 137 Cong. Rec. S. 13979-02 (1991).

11. RAABE, supra note 4 .

12. Id.

13. Id.

14. Butler Brothers v. McColgan, 315 U.S. 501 (1942). 
on the theory that the taxpayer was a unitary business. The formula averaged the percentage payroll, property, and sales within California in comparison to the payroll, property, and sales outside California. The effect of the apportionment formula was to erase an $\$ 82,581$ loss at the California branch and apportion $\$ 175,000$ of income to California. The case turned largely on the relationship between the California branch and the Chicago home office.

The taxpayer claimed that California, in violation of the Due Process clause, reached beyond its jurisdiction to tax revenue generated in other states. The taxpayer emphasized several facts to reveal the autonomy of the California branch office and to demonstrate the appropriateness of a separate accounting. Among the facts favorable to the taxpayer were that the branch office maintained its own inventory, serviced a designated sales territory, employed its own sales force, and kept its own books, including the accounts receivable. California countered by showing that the Chicago home office purchased all inventory and shipped it to the seven branch offices and that the cost of the home office was absorbed by the seven branch offices.

The Court held that the taxpayer was a "unitary enterprise and the formula was a proper method to establish taxable income." 15 The Court supported its holding by stating that

[i]t is true that appellant's separate accounting system for its San Francisco branch attributed no net income to California. But we need not impeach the integrity of that accounting system to say that it does not prove appellant's assertion that extraterritorial values are being taxed. Accounting practices for income statements may vary considerably according to the problem at hand. A particular accounting system, though useful or necessary as a business aid, may not fit the different requirements when a State seeks to tax values created by business within its borders. That may be due to the fact, as stated by Mr. Justice Brandeis in Underwood Typewriter Co. v. Chamberlain, ... that a state in attempting to place upon a business extending into several States "its fair share of the burden of taxation" is "faced with the impossibility of allocating specifically the profits earned by the processes conducted within its borders." Furthermore, the particular system used may not reveal the facts basic to the State's determination. In either aspect of the matter the results of the accounting

15. Id. at 506 . 
system employed by appellant do not impeach the validity or propriety of the formula which California has applied here. ${ }^{16}$

Thus, how a unitary business is defined for state taxation purposes may have a dramatic impact on the taxpayer and the states' revenues. With the growth of the unitary business principle, taxpayers have increasingly complained, as in Butler Bros., that states are reaching beyond their borders and subjecting corporations to double taxation. At the time Butler Bros. was decided, double taxation was a valid concern because the unitary business principle operates as intended only if all fifty states are using the same apportionment formula. Because of the concern of double taxation, uniformity in state taxation became essential.

\section{B. Uniform Division of Income for Tax Purposes Act (UDITPA)}

In an effort to bring uniformity to state taxation, the National Conference of Commissioners on Uniform State Laws drafted, in 1957, the Uniform Division of Income for Tax Purposes Act (UDITPA). ${ }^{17}$ UDITPA was enacted by the states to protect interstate businesses from arbitrary tax assessments and to minimize double taxation of interstate commerce. ${ }^{18}$

These goals are accomplished by a three-factor formula which apportions a business's income to a state by computing an average based on the percentage of a business's payroll, property, and sales within that state. ${ }^{19}$ The resulting percentage is multiplied by business income, as opposed to non-business income which is allocated to the state of commercial domicile. ${ }^{20}$ Theoretically, if all of the states use the same apportionment formula and the same definition of business income, the states will only tax one hundred percent of the business's taxable income. UDITPA allows for a state to alter or disregard the

16. Id. at 507-08 (citations omitted).

17. Unif. Division of Income for TAX Purposes Act, 7A U.L.A. 91, S5 4-8 (Master Ed. 1992 Supp.).

18. RAABE, supta note 4 , at I-412.

19. Id.

20. For example, one business is composed of two divisions. One division makes curtains at its plant in Indiana and the other division makes dog food at its plant in Ohio. The curtain plant in Indiana has ten dollars of payroll, property, and sales in Indiana. The dog food plant in Ohio has twenty dollars of payroll, property, and sales in Ohio. The business's total income for the fiscal year is 100 dollars. Using the UDITPA formula, Indiana may tax thirty-three dollars of the business's income $((10 /$ $30+10 / 30+10 / 30) / 3 \times 100)$, and Ohio may tax sixty-six dollars of income $((20 / 30$ $+20 / 30+20 / 30) / 3 \times 100)$. 
apportionment formula if it would produce an unfair result. Twentythree states, including California, have enacted UDITPA. ${ }^{21}$

The principles of apportionment and the unitary business are firmly entrenched in the field of state taxation. Writing for the majority in Mobil Oil Corp. v. Commissioner of Taxes of Vermont, Justice Blackmun declared that "the linchpin of apportionability in the field of state income taxation is the unitary business principle." 22 The states quickly expanded the principle to include businesses based in foreign countries.

\section{The Unitary Business and Division of Net Income Among Nations: Container Corp.}

Apportioning a business's income among the states by a threefactor formula became widely accepted, but problems surfaced when states required businesses to apportion income derived from operations outside the United States. ${ }^{23}$ Foreign trading partners condemned the states for reaching beyond their jurisdictions for revenues. ${ }^{24}$ In the early 1980 's, six states required a multinational corporation to apportion its worldwide income, with California receiving the most attention. ${ }^{25}$

The Supreme Court addressed the constitutionality of worldwide unitary taxation in the 1983 case of Container Corp. of America v. Franchise

21. Applications of the Unitary Business Doctrine, 1 Multistate Corporate Income Tax Guide (CCH) I 809 (1991).

22. Mobil Oil Corp. v. Commissioner of Taxes of Vermont, 445 U.S. 425, 439 (1980).

23. Returning to the earlier example, supra note 20 , and adding some additional facts, the dog food plant, if located in China, is responsible as a profit center for sixty dollars of the income, and the curtain plant in the United States is responsible for forty dollars of income. The United States' tax rate on income is ten percent $(10 \%)$ and China's tax rate on income is twenty percent (20\%). Assuming that the business is a profit-maximizing enterprise, the business will argue that the two divisions are separate entities deserving of separate accounting. Since apportionment is unnecessary, the dog food plant in China will have a tax bill of twelve dollars $(60 \times 20 \%)$ and the curtain plant will have a tax liability of four dollars $(40 \times 10 \%)$ for a total of sixteen dollars. If the two divisions were a unitary business, they would have to apportion their income between the two countries which would result in a tax liability of 16.33 dollars $((20 \% \times 66)+(10 \% \times 33))$.

24. Akio Morita, the Chairman and CEO of Sony Corporation said, "[w]hat would happen if Tokyo or London wanted to tax the income U.S. companies earned in the U.S.?" Margaret Thatcher, the former Prime Minister of England, stated: " $[\mathrm{m}] \mathrm{y}$ worry is that if they (Donald Regan's Working Group who were addressing the unitary taxation issue) don't work fast enough, we might be under very severe pressure to take retaliatory measures." Note, State Worldwide Unitary Taxation: The Foreign Parent Case, 23 J. Transnat'L L. 445, 446-47 (1985).

25. California, Idaho, Montana, New Hampshire, North Dakota and Alaska. 
Tax Board. ${ }^{26}$ The taxpayer (Container Corp.) manufactured paperboard packaging beginning with the harvest of timber and ending with the final product. Twenty foreign subsidiaries were partially or wholly owned by the taxpayer. The taxpayer omitted the income from the twenty foreign subsidiaries, deducted the subsidiaries' dividends from its taxable income, and excluded the subsidiaries' property, payroll, and sales from its apportionment formula.

Upon audit for the 1963, 1964, and 1965 tax years, California treated the taxpayer and its foreign subsidiaries as a unitary business. In other words, California added the foreign subsidiaries' income and dividends to their taxable income, and included the subsidiaries' property, payroll, and sales in the apportionment formula. The audit adjustments increased the taxpayer's tax liability in each of the three years. Before the Supreme Court, the taxpayer challenged the auditor's adjustments on three grounds.

First, the taxpayer asserted that the taxpayer and its foreign subsidiaries were not a unitary business. Because there was no flow of goods between the subsidiary and the taxpayer, the taxpayer argued that the trial court's finding was in error. In evaluating the utility of this "bright line" test for a unitary business, the Court said:

[t]he prerequisite to a constitutionally acceptable finding of a unitary business is a flow of value, not a flow of goods. As we reiterated in $F$.W. Woolworth, a relevant question in the unitary business inquiry is whether "contributions to income [of the subsidiaries] result[ed] from functional integration, centralization of management, and economies of scale. . .." Substantial mutual interdependence can result in any number of ways $\ldots .^{27}$

While no flow of goods existed between the subsidiaries and the taxpayer, the taxpayer assisted the subsidiaries in obtaining equipment and personnel, receiving financing, providing technical assistance, and advising its corporate officers. In regard to issue one, the Court held that the trial court's finding of a unitary business was "within the realm of permissible judgment," given the combination of facts. ${ }^{28}$

26. Container, 463 U.S. at 159. For other cases which addressed unitary taxation before, see supra note 6 .

27. Id. at $178-79$ (quoting F.W. Woolworth, 458 U.S. at 371) (footnote and citations omitted).

28. Id. at $\mathbf{1 8 0}$. 
Second, the taxpayer argued that the apportionment formula was distorted because of the differences between the United States and other national economies. The taxpayer criticized California's apportionment formula on two grounds. The taxpayer argued that the sales, payroll, and property factors were indirect measures of income, and that because the foreign subsidiaries were more profitable, California expropriated more income than was due. The taxpayer's second criticism was:

[t]he costs of production in foreign countries are generally significantly lower than in the United States, primarily as a result of the lower wage rates of workers in countries other than the United States. Because wages are one of the three factors used in formulary apportionment, the use of the formula unfairly inflates the amount of income apportioned to United States operations where wages are higher. ${ }^{29}$

The taxpayer produced extensive evidence revealing the wage scales in foreign countries. In essence, the taxpayer demonstrated that formula apportionment resulted in a more severe misattribution of income, nearly fourteen percent, when compared to the results of geographic or separate accounting.

In response, the Court answered that geographical accounting, the method urged by the taxpayer and accepted by the Internal Revenue Code (hereinafter "I.R.C."), and formula apportionment are "imperfect proxies for an ideal which is not only difficult to achieve in practice, but also difficult to describe in theory." ${ }^{30}$ In recognition that the three-factor apportionment formula was imperfect, the Court relied on Hans Rees' and Sons, Inc. to demonstrate a constitutionally impermissible apportionment error ${ }^{31}$ Contrasting the present case in which the taxpayer complained of a fourteen percent error to Hans Rees' and Sons, the Court said that the taxpayer's complaint of a fourteen percent error was a "far cry from the more than $250 \%$ difference which led us to strike down the state tax in Hans Rees' Sons, and a figure certainly within the substantial margin of error inherent in any method of attributing income among the components of a unitary business.",32 The Court found that geographic accounting was not a better alternative.

29. Id. at 181-82.

30. Id. at 182 .

31. Id. at 184 (citing Hans Rees' and Sons, Inc. v. North Carolina ex rel. Maxwell, 283 U.S. 123 (1931)).

32. Id. at 184 . 
Third, the taxpayer in Container contended that California violated the foreign Commerce Clause by interfering with the federal government's foreign policies. When the Commerce Clause is implicated in the taxation of interstate commerce, a four-prong test, derived from Complete Auto Transit v. Brady, is used to determine the tax's constitutionality: (1) does the taxing state have a nexus; (2) is the tax fairly apportioned to the entity's in-state activities; (3) does the tax discriminate against interstate commerce; and (4) has the state conferred a benefit for which compensation may be asked? ${ }^{33}$

When the Commerce Clause is implicated in the taxation of international trade, two additional tests are used because of the "sensitive matters of foreign relations and national sovereignty . . ." "34 The first test under Japan Line, Ltd. v. County of Los Angeles asks whether the tax subjects international commerce to a greater likelihood of double taxation than domestic commerce..$^{35}$ The second test under Japan Line asks whether the state tax will " "impair federal uniformity in an area where federal uniformity is essential' and '[prevent] the federal government from speaking with one voice in international trade'."36 The combination of Complete Auto and Japan Line results in the foreign Commerce Clause.

The Container Court dismissed the first test imposed under Japan Line stating that the use of arms-length accounting was no better guarantee against double taxation than apportionment. ${ }^{37}$ Turning to the second issue, the Court stated that the "one voice standard" is violated when a state tax "either implicates foreign policy issues which

33. Complete Auto Transit v. Brady, 430 U.S. 274 (1977). Since 1977, Complete Auto has served as the Court's touchstone in the adjudication of Commerce Clause cases. "After decades of distinctions based upon insubstantial and pointless formalism, in 1977 the Court cut the Gordian knot [of confusion] in Complete Auto. . . " PAUL. J. Hartman, Federal Limitations on State and local Taxation, $\int 2: 17$ (1981).

34. Japan Line, Ltd. v. County of Los Angeles, 441 U.S. 434, 456 (1979).

35. Id. at 447-48.

36. Container, 463 U.S. at 194, quoting Japan Line, 441 U.S. at 448 and 453. "A state tax on instrumentalities of foreign commerce may frustrate the achievement of federal uniformity in several ways. If the state imposes an apportioned tax, international disputes over reconciling apportionment formulae may arise. If a novel state tax creates an asymmetry in the international tax structure, foreign nations disadvantaged by the levy may retaliate against American-owned instrumentalities present in their jurisdictions ..... If other States followed the taxing State's example, various instrumentalities of commerce could be subjected to varying degrees of multiple taxation, a result that would plainly prevent this Nation from 'speaking with one voice' in regulating foreign commerce." Japan Line, 441 U.S. at 450-51.

37. Container, 463 U.S. at 194. 
must be left to the federal government or violates a clear federal directive." 38

The clearest implication of foreign policy is if a state tax would cause a foreign trading partner to retaliate against the nation as a whole. The Court recognized its weaknesses in addressing foreign policy issues, but nevertheless made the following three observations to justify its conclusion that the state tax would not lead to retaliation by foreign trading partners:

[f]irst the tax here does not create an automatic "asymmetry" in international taxation. Second, the tax here was imposed ... on a domestic corporation. Although, California "counts" income arguably attributable to foreign corporations in calculating the taxable income of that domestic corporation, the legal incidence of the tax falls on a domestic corporation. Third, even if foreign nations have a legitimate interest in reducing the tax burden of domestic corporations, the fact remains that appellant is without a doubt amenable to be taxed in California in one way or another, and that the amount of tax it pays is much more the function of California's tax rate than of its allocation method. ${ }^{39}$

Ultimately, the Court found that the "foreign policy of the United States . . . is not seriously threatened by California's decision to apply the unitary business concept ...." "40

The Court next examined whether California had violated any specific manifestation of Congressional intent, and found that it had not. The Court noted that treaties of the federal government did not bind the states or forbid the states from using the unitary business principle. Additionally, the Court noted that legislation which forbid unitary taxation was pending. ${ }^{41}$ Nonetheless, the Court held that the California tax at issue was not pre-empted by federal law nor fatally inconsistent with federal policy. ${ }^{42}$

\section{Analysis of Worldwide Unitary Taxation}

The Container case illustrates the primary arguments that are most often discussed regarding unitary taxation. Among the most common

38. Id. at 194 .

39. Id. at 195 (footnote omitted).

40. Id. at 195-96. The Court recognized in a footnote that the federal government filed an opposing brief to unitary taxation in Chicago Bridge \& Iron Co. v. Caterpillar Tractor Co., 463 U.S. 1220 (1983), a case which was subsequently dismissed. Id.

41. The bill was H.R. 2918, 98th Cong., 1 st Sess. (1983).

42. Container, 463 U.S. at 198. 
complaints against unitary taxation are that it differs drastically from the federally required separate accounting and that it damages foreign relations. Yet the states maintain that unitary taxation is necessary to prevent companies from manipulating transfer prices and allocating income to jurisdictions with lower tax rates.

\section{A. Weaknesses of Unitary Taxation}

\section{Differs from the Federal Government's Use of Separate Accounting}

The most persuasive argument against unitary taxation is that it differs from the federal government's use of separate accounting. ${ }^{43}$ Separate accounting is the internationally accepted method for attributing income among nations. By way of background, the federal government's attribution of income among nations will be explained.

The I.R.C. treats a corporation differently depending on whether a corporation is incorporated in the United States or incorporated in a foreign country. ${ }^{44}$ When a company is incorporated within the United States, the domestic company is taxed on all its income, regardless of whether the income is from a domestic or foreign source..$^{45}$ The domestic company is not required to segregate income received from foreign and U.S. sources, but must combine the two. ${ }^{46}$ Because income from a foreign source could be subject to double taxation, once in the United States and once in the foreign country, the I.R.C. provides a credit for a domestic company when the company pays taxes to a foreign country. ${ }^{47}$ If a corporation is incorporated under the laws of a foreign country, then the corporation must determine the amount of income derived solely from U.S. sources. ${ }^{48}$ These are the general rules; however, they are riddled with exceptions. ${ }^{49}$

43. Jerome R. Hellerstein, State Taxation: Corporate Income and FranCHISE TAXES, 5 8.10[7][a] (1983).

44. Michael D. Rose \& John C. Chommie, Federal Income Taxation 680764 (3d ed. 1988).

45. I.R.C. SS 861 and 882 (1986).

46. Id.

47. I.R.C. SS 901-11 (1986).

48. I.R.C. S\$ $861-97$ (1986).

49. "It follows from these general rules that the taxpayer's identity is only one of serveral important determinations that must also be made to ascertain the United States tax consequences of any given foreign-related transaction. The source of the income, the type of income (rent, royalty, interest, capital gain, or business), and whether the income is effectively connected with the conduct of a U.S. trade or business must be determined as well." Rose, supra note 44 , at 682 . 
Under the federal approach, the states would only apportion the income from U.S. sources. Thus, the three-factor apportionment formula would no longer be property, payroll, and sales within the state divided by total worldwide property, payroll, and sales. ${ }^{50}$ Instead, the apportionment formula would consist of the property, payroll, and sales within the state over property, payroll, and sales within the United States. By adopting the federal or separate accounting approach, the compliance and administrative burdens of an MNC would be greatly eased in several respects.

The primary benefit would be a reduction in the cost of compliance for an MNC. ${ }^{51}$ In order for a multinational corporation to calculate the apportionment formula for a unitary state, the corporation must obtain property, payroll and sales data from other countries. ${ }^{52}$ Such an endeavor might involve locating and then examining records maintained halfway around the world. ${ }^{53}$ Even when the records are found, they might be in a format which complies with the law of the foreign county, but which is unacceptable to state officials in the United States. ${ }^{54}$ Additionally, the entries required for computing the apportionment formula might be omitted from the records all together ${ }^{55}$ Finally, records located in foreign countries are usually in the currency of that country and would require a conversion to U.S. dollars. ${ }^{56}$

\section{Damages Foreign Relations}

Companies continually complain that unitary taxation violates the federal government's policies on two grounds. First, borrowing from the language in Container, companies assert that unitary taxation prevents the federal government from "speaking with one voice" in international matters. ${ }^{57}$ Second, companies contend that unitary taxation frustrates congressional policy. Although these arguments were dismissed in Container, subsequent actions by the federal government have made these arguments more viable.

50. See supra note 7. I-414.

51. Hellerstein, supra note 43 , at par. 8.10[7][a]; RAABE, supra note 4, at

52. Hellerstein, supra note 43 , at par. 8.10[7][a].

53. Id.

54. Id.

55. Id.

56. Id.

57. Container, 463 U.S. at 448 . 
The force of these arguments was finally tested in Colgate-Palmolive Co. v. Franchise Tax Bd. ${ }^{58}$ The case was eagerly awaited because the trial court held that unitary taxation contradicted federal policy and thus invalidated California's use of unitary taxation. On appeal, counsel for Colgate argued that the executive branch's actions following the Container decision clearly indicated that unitary taxation impermissibly interfered with foreign policy. ${ }^{59}$ In support of its position, Colgate's counsel and the trial court cited five actions by the executive branch: (1) a 1985 statement by President Ronald Reagan, (2) a 1986 letter from Secretary of State George Shultz to California governor George Deukmejian, (3) two letters by Department of Justice attorneys, (4) a 1986 letter from Treasury Secretary James Baker to the chairman of the Senate Finance Committee and, (5) an amicus trial brief filed in Barclays Bank $v$. Franchise Tax $B d .{ }^{60}$ The court addressed each action in turn.

The court first addressed President Reagan's letter which was largely inspired by the findings of the Worldwide Unitary Taxation Group ("Working Group"). The Working Group was formed in 1983 at the request of domestic and foreign businesses and was chaired by the then Secretary of the Treasury Donald Regan. The Working Group recommended the abandonment of unitary taxation in favor of a water's edge election. President Reagan included this recommendation in his 1985 statement:

[s]ince early in this Administration, we have been working with the states, the business community, and foreign governments in an effort to resolve issues related to state use of the worldwide unitary method of taxation. At this time I believe it appropriate for the Federal Government to state its support for the concept of legislation that would: 1. Effect a requirement that multinationals be taxed by states only on income derived from the territory of the United States (the water's edge requirement). ... Since states have not universally accepted these principle[s], I am instructing the Secretary of the Treasury to initiate ... legislation .... Further, I am instructing the Attorney General to ensure that the United States'

58. Colgate-Palmolive Co. v. Franchise Tax Bd., 284 Cal. Rptr. 780 (Cal. Ct. App. 1991), transfer granted, 2 Cal. Rptr. 2d 2 (Cal. 1991).

59. Id. at 783.

60. Id. 
interests are represented in appropriate controversies and cases consistent with this approach. ${ }^{61}$

The court acknowledged the significance of President Reagan's statement, but was perplexed over the Attorney General's failure to file a brief in such an important case. Before drawing any conclusions, the court next turned to the second and third instances of executive action.

The second action by the executive branch was the 1986 letter by Secretary of State Shultz which noted that "unitary taxation is at odds with the 'arm's length' accounting method which is the international rule . . . . [T] he arm's length method . . . is essential to avoid adverse consequences for the foreign relations of the United States." court held that these two statements by Reagan and Shultz were virtually meaningless because the Attorney General filed briefs only in cases where the parent of the unitary group was located in a foreign country. ${ }^{63}$ In short, the court found the statements inapplicable because of the Attorney General's inaction in the case at hand.

The court also held that the third instance of executive action, the two letters by the attorneys for the Department of Justice, was virtually meaningless for the same reasons. ${ }^{64}$ The court stated, "the executive branch was twice explicitly notified about this case. This case could not have provided a more appropriate context for the executive branch to express its views regarding the application of the worldwide unitary method to domestic-parent groups with foreign subsidiaries." 65 Despite the notification, the federal government remained silent in regard to this case.

The court turned next to the fourth action by the executive branch, which was a letter by Secretary of the Treasury James Baker to Senator Bob Packwood, chairman of the Senate Finance Committee. Secretary Baker addressed virtually the same issues as were discussed in Secretary Shultz's letter. With the content being consistent with Secretary Shultz's letter, the court easily restricted Baker's remarks to foreign-based parent groups. ${ }^{66}$

The court finally reached the fifth instance of executive action, a brief filed by the Attorney General in the worldwide unitary case Barclays

61. Id. at 793 (emphasis added).

62. Id. at 795 .

63. See Barclays Bank Int'l v. Franchise Tax Bd., $275 \mathrm{Cal}$. Rptr. 626 (Cal. Ct. App. 1990), rev'd, 8 Cal. Rptr. 2d 31 (Cal. 1991).

64. Colgate, 284 Cal. Rptr. at 795.

65. Id. at 796 .

66. Id. at 797 . 
Bank Int'l v. Franchise Tax $B d .{ }^{67}$ In regard to this last instance of executive action, the court stated that "the Alaska suit involved the application of the worldwide unitary tax method to a foreign-parent group and it was on that basis that the United States sought a judgment declaring the method unconstitutional. Rather than support Colgate's foreign commerce clause argument, the Alaska case undermines it." 68

Under the two-prong standard announced in Container, the court was obligated to determine (1) whether California's application of unitary taxation "implicates foreign policy issues which must be left to the Federal Government," and (2) whether California violated a clear federal directive. ${ }^{69}$ In answering the first question, the court said that the five actions by the executive branch

show that the foreign commerce problem is essentially limited to foreign-parent groups and does not materially involve their domestic-parent counterparts. ... Therefore, the statement and letters from the executive branch officials do not constitute, either individually or collectively, an authoritative expression of the federal government that state application of the worldwide unitary tax method to domestic-parent groups with foreign subsidiaries implicates foreign policy issues which must be left to the federal government. ${ }^{70}$

In answering whether California violated a clear federal directive, the court said, Congress had remained silent since the Container decision; therefore, the issue was primarily a domestic concern which limited the executive's power to compel compliance by the states. ${ }^{71}$ The court said that California did not violate a clear federal directive and emphasized the executive branch's failure to file an amicus brief. ${ }^{72}$ In sum, the Court held that California did not violate the foreign Commerce Clause despite the executive branch's actions since the Container decision. ${ }^{73}$

\section{B. Strength of Unitary Taxation: Avoidance of Income Shifting}

Although the adoption of the federal rules for foreign income would reduce an MNC's compliance burden, their adoption might lead to

67. Barclays Bank, $275 \mathrm{Cal}$. Rptr. at 626.

68. Colgate, 284 Cal. Rptr. at 799.

69. Id. at 787 (quoting Container Corp. of Am. v. Franchise Tax Bd., 463 U.S. 159,194 (1983)).

70. Id. at 798.

71. Id. at 799 .

72. Id.

73. Id. at 800 . 
unfair transfer pricing. ${ }^{74}$ For example, assume a U.S. car company possesses a wholly owned Mexican subsidiary which makes transmissions. Assume further that Mexico has no income tax and the United States will impose a thirty-one percent income tax. The two companies will want the income from the two divisions to be taxed in Mexico because Mexico has no income tax. Therefore, the Mexican subsidiary will charge very high prices for its transmissions. The effect of this overpricing will be to shift income from the United States to Mexico. Under the states' unitary tax method, transfer prices will make no difference because the two entities will be treated as a unitary businesses and intercompany transfers will be irrelevant. However, these intercompany transfers will affect federal taxable income.

This scheme of income shifting led the federal government to enact I.R.C. section 482. Under I.R.C. section 482, arm's length prices are regularly established which serve to limit what a Mexican subsidiary may charge. In 1981, the General Accounting Office (hereinafter "GAO") did a study on the effectiveness of I.R.C. section 482. The GAO's conclusion was that the system was not working effectively. The GAO recommended that:

[t]he current Treasury regulations for implementing code section 482 create uncertainty and an administrative burden for both IRS and corporate taxpayers. Since better guidelines are needed, GAO recommends that the Secretary of the Treasury:

- Begin a study to identify and evaluate the feasibility of ways to allocate income under section 482 , including formula apportionment, which would lessen the present uncertainty and administrative burden created by the existing regulations. ${ }^{75}$

Thus, unitary apportionment's strength, the ability to ignore transfer prices, is section 482's weakness.

\section{California and the Water's Edge Election}

California no longer requires an MNC to apportion income from all unitary entities. ${ }^{76}$ Instead, a multinational corporation may choose

74. "Historically, separate accounting was the method preferred by both tax administrators and taxpayers .... The Achilles heel of separate accounting is the inability to establish fair arm's length prices for goods tranferred, or basic operational services rendered, between controlled branches or subsidiaries. . ." Hellerstein, supra note 43, at 9 8.10[2] (footnote omitted).

75. Hellerstein, supta note 43 , at $98.10[7][\mathrm{b}] \mathrm{n}$. 270.

76. $1986 \mathrm{Cal}$. Stat. c. 660 , sec. 6 . This statute was subsequently amended by 1988 Cal. Legis. Serv. 160 (West) and 1988 Cal. Legis. Serv. 989 (West). 
a water's edge election which effectively limits the business's income to income earned within the United States. "A qualified taxpayer ... may elect to determine its income derived from or attributable to sources within this state pursuant to a water's edge election ...."77 The California legislature's critical question was who, if not all unitary businesses, was subject to its taxing jurisdiction.

A taxpayer qualifies for the water's edge election if the bank or corporation meets two conditions: first, the taxpayer must consent to the taking of depositions and acceptance of subpoena duces tecum, ${ }^{78}$ and second, the taxpayer must agree to treat dividends as business income when the taxpayer owns a majority interest, fifty percent or more, of the business's voting shares and when the taxpayer and the business have significant intercompany transfers. ${ }^{79}$ Thus, any taxpayer who meets these requirements is entitled to a water's edge election.

In making a water's edge election, the taxpayer must account for income and apportionment of seven "affiliated" entities. A bank or corporation is "affiliated" with another entity when: (1) the bank or corporation owns fifty percent or more of the entity, (2) the entity owns fifty percent of the bank or corporation, or (3) the entity and the bank or corporation are both owned by a person or bank holding a fifty percent or more stake in both. ${ }^{80}$ The seven affiliated entities are:

(1) affiliated banks or corporations eligible to file a federal consolidated return;

(2) domestic international sales corporations and foreign sales corporations;

(3) corporations with twenty percent or more of the average of their property, payroll, and sales factors within the United States;

(4) banks and corporations incorporated within the United States of which more than fifty percent of their stock is controlled by interests not eligible to file a federal consolidated return;

77. Cal. Rev. \& Tax. Code $\$ 25110$.

78. Id. at $25110(\mathrm{~b})(2)$.

79. Id. The criteria for determining when dividends are treated as business income are derived from ASARCO Inc. v. Idaho State Tax Comm'n, 458 U.S. 307 (1982), and F.W. Woolworth Co. v. Taxation \& Revenue Dept. 458 U.S. 354 (1982). 80. Id. at S $25110(\mathrm{~b})(1)$. 
(5) banks and corporations not covered elsewhere in the provisions but only to the extent that they are engaging in business within the United States;

(6) export trade corporations;

(7) affiliated banks and corporations that are controlled by foreign corporations. ${ }^{81}$

To take the water's edge election, a corporation must first be "affiliated" and then be one of the seven entities listed. ${ }^{82}$ Essentially the requirement that the corporation must first be affiliated is a requirement that the corporation be unitary. ${ }^{83}$

The statute's meaning is somewhat obscure, but one commentator attempted a clarification,

[m] any taxpayers believe the water's-edge legislation dispenses with the concept of worldwide unitary combined reporting and allows taxpayers to limit their combined group to U.S. corporations .... Others believe the legislation completely eliminates or substantially alters California's unitary taxation concept. In truth, the legislation does neither. It simply allows taxpayers to elect to limit the reach of California's taxing jurisdiction to those activities occurring within the boundaries of the United States. Thus, the concept of electively limiting California's ability to tax the "water's edge" applies to activities, not corporations. ${ }^{84}$

In other words, if a group of corporations was required to file a combined return under prior California law because it was a unitary business, then a "water's edge election can result only in the exclusion of certain members from the reporting group [or unitary group]." 85 Specifically, the only unitary business member which is excluded under the water's edge election is a foreign based corporation having less than twenty percent of its operations in the United States. ${ }^{86}$

The water's edge election, a contract signed between the taxpayer and the Franchise Tax Board, is effective only if every taxpayer which

81. Id. at $\$ 25110(\mathrm{a})(1)-(7)$.

82. Jan A. Rosati and Carl G. Knopke, California Unitary Tax Reform Law, 6 J. St. TAX'N 45, 48 (Spring 1987).

83. Jurinski, supra note 8 , at 105.

84. Id. at 103 .

85. Id. at 105 .

86. Ruurd G. Leegstra, et al., The California Water's-Edge Election, 14 ThE INT'L TAX J. 101, 102 (1987). 
is a member of the water's edge group makes the election, and each contract is for an initial term of five years. ${ }^{87}$ Each contract executed by the taxpayer is subject to an annual tax amount. ${ }^{88}$ The amount is equal to "thirty-thousandths of 1 percent of the sum of the taxpayer's property and payroll assigned to this state for an income year of twelve full months ... . "89

\section{Conglusions on California's Water's Edge Election}

California's new water's edge election is an ineffective solution to the problems caused by worldwide unitary taxation for two reasons: (1) it maintains the worldwide unitary method and (2) the election fee discriminates against multinationals with foreign businesses.

The water's edge election maintains the concept of worldwide unitary taxation. The statute requires that an MNC first determine if a unitary relationship exists between itself and its foreign subsidiary. Thus, the two weaknesses of unitary taxation remain. First, the high administrative and compliance costs are necessary because a determination of a unitary business involves an examination of the relationship between the MNC and foreign subsidiary. This determination is fact sensitive, produces litigation, and requires substanitation by domestic and foreign accounting records. Even if an MNC finds, in good faith, that it is not a unitary business, California may audit the MNC and find a unitary relationship. So long as California's decision is "in the realm of permissible judgment," reversing the audit findings.

Second, worldwide unitary taxation will continue to irritate U.S. trading partners, which might produce retaliatory legislation against the federal government. Forty United Kingdom companies oppose the legislation on the grounds that a water's edge election is not a privilege which requires the payment of a fee. ${ }^{91}$ The group contends that worldwide unitary taxation has been historically wrong, and the new legislation essentially recognizes worldwide unitary method as a legitimate method of taxation. Initially, the federal government was so pleased with California's water's edge enactment that it withdrew its support from a congressional bill pre-empting the use of worldwide unitary

87. Cal. Rev. \& Tax. Code $\$$ 25111(a) (West Supp. 1991).

88. Cal. Rev. \& Tax. Code 25115(b) (West Supp. 1991).

89. Id.

90. Container Corp. of Am. v. Franchise Tax Bd., 463 U.S. 159, 180 (1983).

91. Jurinski, supra note 8 , at 35 . 
taxation. However, upon further reflection, the Reagan administration was critical of the election fee, the treatment of U.S. 80/20 corporations, and the treatment of foreign dividends..$^{92}$ Obviously, one of the grounds that a taxpayer will continue to use for protesting an assessment is that worldwide unitary taxation contravenes the federal policies of the United States.

The third shortcoming of California's enactment is that it demands a fee in exchange for making a water's edge election. By demanding a fee, California forces an MNC to calculate worldwide property, sales, and payroll. Assuming the MNC is a profit maximizing entity, it will calculate the taxable income of the unitary business and California's apportionment percentage. The taxable income attributed to California will be compared to the taxable income to California when the water's edge election fee is taken. The MNC will presumably choose the lesser of the election fee or California tax. Such calculations will be just as expensive and suffer the same flaws as discussed earlier..$^{93}$ Because the water's edge contract is for a term of five years, one might conclude that the cost of calculating the unitary tax will be one-fifth of what it was prior to the election. However, these savings might be overstated because one might just as easily conclude that the magnitude of the decision would involve five-year projections. Nevertheless, an MNC will endure considerable costs to decide whether to take the water's edge election.

California's water's edge election is a hybrid between the traditional separate accounting method and worldwide unitary taxation. The blending of the two concepts may inspire an abundance of litigation in the next several years as California completes its audits of MNCs. ${ }^{94}$ The failure of California to choose between either concept will further compound the inconsistencies between California and the federal government. Because separate accounting and unitary taxation have serious flaws, the introduction of the Domestic Corporation Taxation Equality Act of 1991 may serve as a vehicle for further discussion and solve a

92. Id.

93. See supra notes 43-72.

94. Two California cases have expressly refused to address the constitutionality of the new water's edge election. Colgate-Palmolive Co. v. Franchise Tax Bd., 284 Cal. Rptr. 780, fn. 4 (Cal. Ct. App. 1991); and Barclays Bank Int'l v. Franchise Tax Bd., 275 Cal. Rptr. 626, fn. 2 (Cal. Ct. App. 1990). Additionally, the California Legislature enacted a law which mandates all revenues raised by the water's edge election be placed in an escrow account pending a court decision on the constitutionality of the new law. $1990 \mathrm{Cal}$. Stat. c. 467 , sec. 11.61 . 
problem which dates back to the $1970 \mathrm{~s} .{ }^{95}$ Unless a solution is reached, California's water's edge election will likely parallel the evolution of worldwide unitary taxation which caused litigation and harmed foreign relations for many years.

Robert Khuon Wiederstein*

95. S. 1775, 104th Cong., 1st Sess. (1991).

- J.D. Candidate, 1993, Indiana University School of Law-Indianapolis. 